\title{
МЕХАНІЗМ ЧАСТОТНО-НЕЗАЛЕЖНОЇ ЕЛЕКТРОПРОВІДНОСТІ ВОДНИХ РОЗЧИНІВ ЕЛЕКТРОЛІТІВ
}

\author{
Л.А. БУЛАВІН, О.М. АЛЄКСЄЕВ, Ю.Ф. ЗАБАШТА, С.Ю. ТКАЧОВ
}

УДК 537.31, 544.01.

Київський національний університет ім. Тараса Шевченка, фізичний факультет

\begin{abstract}
Показано, що поведінка залежності опору комірки з водним розчином $\mathrm{NaCl}$ від частоти змінного струму в вибраному наближенні не може бути пояснена тільки поляризаційними явищами в граничних областях електрод-електроліт. Запропоновано фізичний механізм, що пояснює монотонне зростання питомої електропровідності розчину при зростанні частоти, коли частота менша за $10^{4}$ Гц, і сталість питомої електропровідності розчину при частотах в інтервалі $\left(10^{4}-10^{5}\right)$ Гц. Розраховано температурні залежності коефіцієнта дифузії іонів $\mathrm{Na}^{+}$i $\mathrm{Cl}^{-}$у водних розчинах $\mathrm{NaCl}$ та розміру фізичного нескінченно малого об'єму (області встановлення локальної рівноваги) для такого електроліту. Проведено аналіз просторової та часової ієрархї у водному розчині $\mathrm{NaCl}$ та показано зв'язок співвідношення періоду змінного струму та певних характерних часів 3 частотною залежністю питомої електропровідності цього електроліту.
\end{abstract}

\section{1. Вступ}

Як відомо [1], коли частота змінного струму менша за $10^{4}$ Гц, при зростанні частоти спостерігається монотонне зростання питомої електропровідності з виходом на плато в інтервалі $\left(10^{4}-10^{5}\right)$ Гц. Щодо такої поведінки висловлюються припущення про те, що вона є проявом поляризаційних явищ у граничній області електроліт-електрод при контактному способі вимірювання. У роботі показано, що такі уявлення мають лише якісне узгодження з експериментальними даними. Мета даної роботи - запропонувати фізичний механізм, який пояснив би сталість електропровідності у вказаному інтервалі частот.

\section{2. Методика експерименту}

Досліджено опір водного розчину натрію хлориду 3 концентраціями $\mathrm{NaCl}$ 0,9; 1,8; 4,5 і 9 г·л за допомогою моста змінного струму Р5083 в інтервалі частот $(0,1-$ 100) кГц і температур $(30-70){ }^{\circ} \mathrm{C}$.

Для вимірювання опору використовували контактну двохелектродну комірку, в яку заливали дослі- джувану рідинну систему. Звичайно таку комірку зображують у вигляді еквівалентної схеми [1], в яку, крім опору електроліту, входять ємність подвійного шару, імпеданс Варбурга, опір електрохімічної поляризації, паразитна ємність між електродами й опір, що утворюється в результаті адсорбції іонів на поверхні електрода. Параметри комірки та електроліту можна підібрати таким чином, аби паразитну ємність, адсорбційний опір та опір електрохімічної поляризації можна було вважати рівними нулю. Наприклад, для мінімізації паразитної ємності замість звичайних електродів у вигляді пластин було використано комірку з зондовими платиновими електродами. За такого спрощення еквівалентної схеми вимірюваний опір комірки з електролітом $R_{\text {вим }}$ і опір електроліту $R$ співвідносяться таким чином:

$R_{\text {вим }}=R+\Delta R_{s}$

де $\Delta R_{s}$ - похибка, яку вносять поляризаційні явища, причому [1]

$\Delta R_{s}=\frac{1}{\eta C^{2}} \omega^{-3 / 2}$

де $\eta$ - константа, $C$ - ємність подвійного шару, $\omega-$ циклічна частота змінного струму $(\omega=2 \pi f$, де $f-$ частота змінного струму).

Діаметр комірки набагато менший за їі довжину $\left(l_{0}=10,1 \mathrm{~cm}, d=0,2\right.$ см), що сприяє кращій термостабілізації під час вимірювання температурної залежності електропровідності.

Частотну залежність опору комірки з електролітом у вказаному інтервалі для водного розчину $\mathrm{NaCl} 3$ концентрацією 9 г·л наведено на рис. 1.

Перебудуємо залежність, зображену на рис. 1, в координатах $\left(\omega^{-3 / 2}, R_{\text {вим }}\right)$ і апроксимуємо її лінійною залежністю, яку дає в цих координатах формула (1) (рис. 2).

Розглянемо цю залежність (експериментальна крива) та їі апроксимацію (теоретична крива) в координатах $\left(f, R_{\text {вим }}\right)$ (рис. 3). Можна побачити, що ці криві 


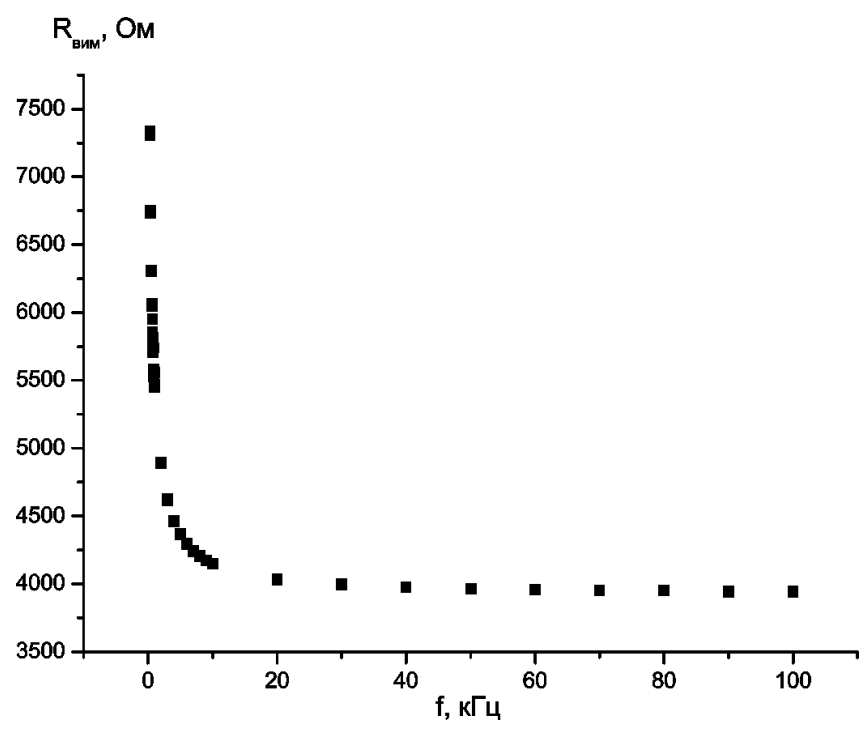

Рис. 1. Залежність опору комірки з водним розчином натрію хлориду з концентрацією $\mathrm{NaCl} 9$ г л від частоти змінного струMy

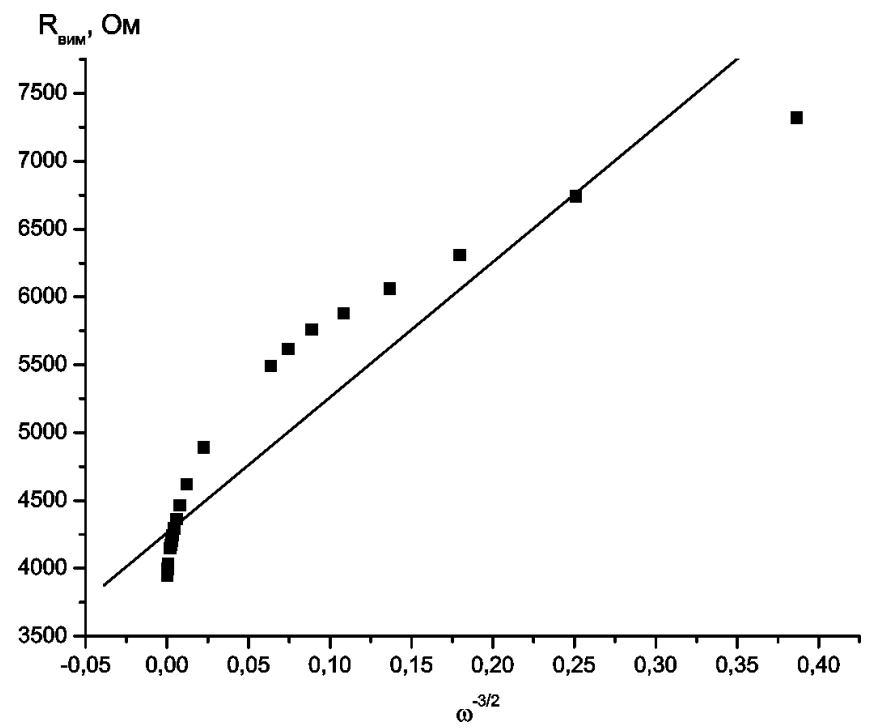

Рис. 2. Залежність опору комірки з водним розчином натрію хлориду з концентрацією $\mathrm{NaCl} 9$ г·л від частоти змінного струму в координатах $\left(\omega^{-3 / 2}, R_{\text {вим }}\right)$ та її апроксимація за формулою (1)

збігаються лише якісно. Це дає підстави припустити, що, крім поляризаційних явищ, існує інша причина того, що залежність вимірюваного опору від частоти має вигляд, зображений на рис. 1.

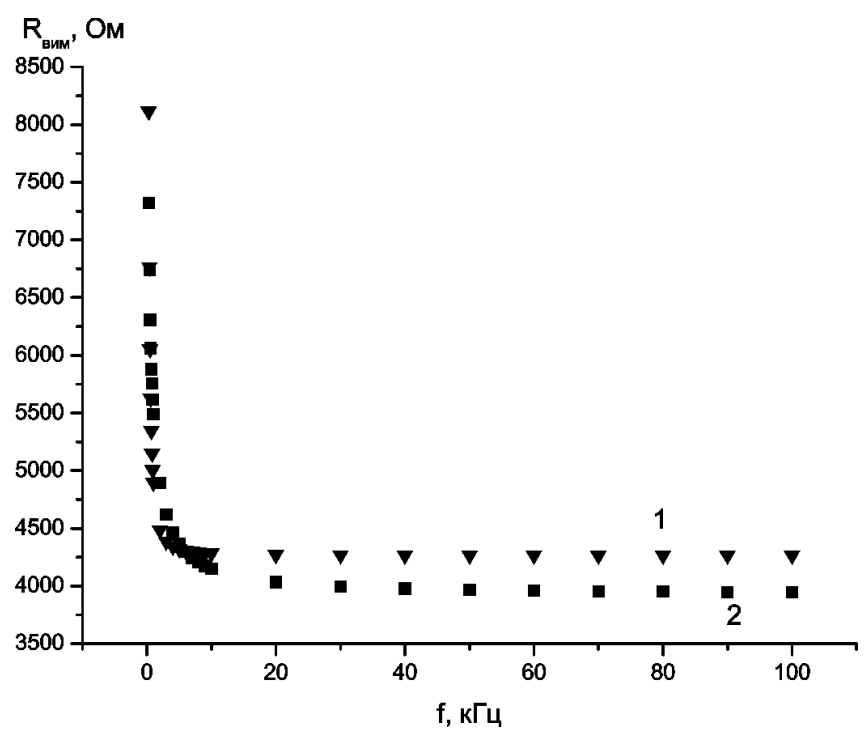

Рис. 3. Залежність 1 - розрахованого за формулою (1), 2 експериментально отриманого опору комірки з водним розчином натрію хлориду з концентрацією $\mathrm{NaCl} 9$ г.л від частоти змінного струму

\section{$\mathrm{k}, \mathrm{CM} / \mathrm{M}$}

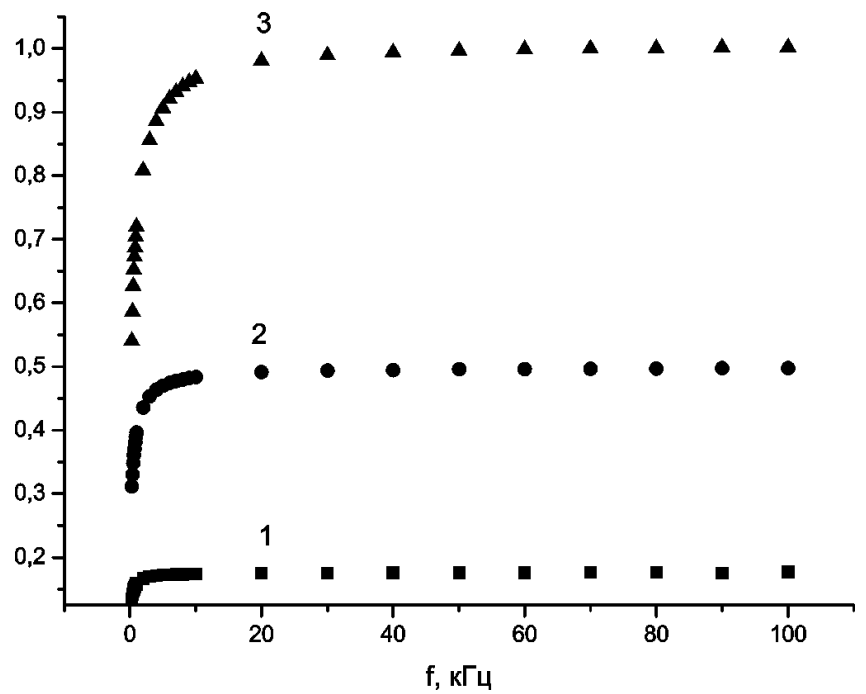

Рис. 4. Залежність питомої електропровідності водного розчину натрію хлориду від частоти змінного струму. 1 - для розчину натрію хлориду з концентрацією $\mathrm{NaCl} 1,8$ г·л, $2-4,5$ г·л, $3-9 \Gamma \cdot \pi$

\section{3. Результати експерименту}

На рис. 4, 5 наведено частотні та температурні залежності питомої електропровідності водного розчину натрію хлориду, розраховані з експериментально отриманих значень опору комірки. 


\section{4. Обговорення результатів експерименту}

При інтерпретації наших експериментальних даних ми будемо використовувати континуальну модель. В основі будь-якої континуальної теорії [2-4] лежить поняття локальної рівноваги. Вважається, що в деякій області із певним розміром $l$ і об'ємом $v \sim l^{3}$ встановлюється неповна рівновага по відношенню до певного обмеженого набору динамічних змінних. Така рівновага й називається локальною, а сама область носить назву фізичного нескінченно малого об'єму. Виникнення останнього терміну пояснюється тим, що в континуальній теорії розмір $l$ розглядається як нескінченно мала величина. Відповідно фізичний нескінченно малий об'єм у континуальному наближенні перетворюється на математичний нескінченно малий об'єм $d \mathbf{x}$.

Існування локальної рівноваги дозволяє приписати фізичному нескінченно малому об'єму певне значення вільної енергії, а, значить, і певне значення деякого макроскопічного параметра. У випадку розчинів електролітів таким параметром може бути, наприклад, концентрація іонів $n$. Ця величина в континуальному наближенні вважається неперервною функцією координат. Відповідно кількість іонів у фізичному нескінченно малому об'ємі із центром мас $\mathbf{x}$ визначається виразом $n(\mathbf{x}) d \mathbf{x}$.

За визначенням [2] кількість частинок у фізичному нескінченно малому об'ємі повинна суттєво перевищувати одиницю. В нашому випадку це означає існування нерівності

$n v \gg 1$.

Саме ця нерівність і визначає правомірність застосування континуального підходу. Введення поняття локальної рівноваги приводить до появи деякого найменшого розміру $l$, в межах якого континуальний підхід стає неправомірним.

За відсутності зовнішнього поля [2] процес дифузії в одновимірному випадку описується рівнянням

$\frac{\partial n}{\partial t}=D \frac{\partial^{2} n}{\partial x^{2}}$

де $D$ - коефіцієнт дифузії.

Розв'язок цього рівняння при нульових граничних умовах записують у вигляді нескінченного ряду

$n=\sum_{q=1}^{\infty} A_{q} \sin \frac{\pi q x}{L} \exp \left(-t / \tau_{q}\right)$

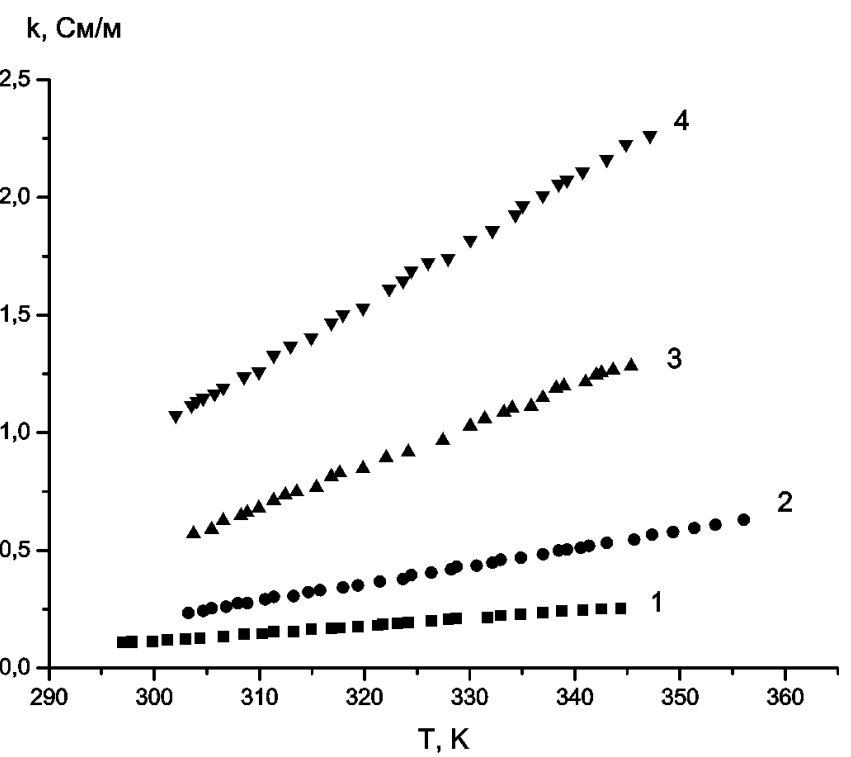

Рис. 5. Температурна залежність питомої електропровідності водного розчину натрію хлориду з концентраціями $\mathrm{NaCl}: 1$ 0,9 г·л, $2-1,8$ г·л, $3-4,5$ г·л, 4 - 9 г·л (виміряна при частоті змінного струму $80 \mathrm{\kappa}$ ц)

де $L$ - розмір системи, $\tau_{q}$ - час релаксації $q$-ї дифузійної моди, який визначається виразом

$\tau_{q}=\frac{L^{2}}{\pi^{2} q^{2} D}$.

Однак, взагалі-то, вираз (5) є наближеним, оскільки, як уже згадувалось, континуальні уявлення справедливі тільки для просторових інтервалів, більших за $l .3$ урахуванням цього більш точним було б записати згаданий розв'язок у вигляді скінченного ряду

$n=\sum_{q=1}^{Q} A_{q} \sin \frac{\pi q x}{L} \exp \left(-t / \tau_{q}\right)$,

де $Q$ - найбільше значення параметра $q$, яке визначається рівністю

$Q=\frac{L}{l}$.

Як це видно із формули (6), із існування найменшого просторового інтервалу $l$ випливає існування найменшого часового інтервалу

$\tau_{Q}=\frac{L^{2}}{\pi^{2} Q^{2} D}$.

Для знаходження величини $l$ використовуватимемо експериментальні дані з електропровідності розчинів 
електролітів. Такий вибір експерименту зумовлений тим, що носіями струму в електролітах, як відомо, є іони. Відповідно для густини сили струму $I$ маємо вираз

$I=e J$

де $e$ - заряд іона, $J$ - густина потоку іонів. Як відомо 3 [6], при дії зовнішньої сили густина потоку іонів $J$ записується у вигляді суми

$J=J_{\mathrm{D}}+J_{\mathrm{K}}$

в якій $J_{\mathrm{D}}$ відповідає дифузійній, а $J_{\mathrm{K}}-$ конвективній густині потоку.

Для згаданих доданків маємо вирази

$J_{\mathrm{D}}=-D \frac{\partial n}{\partial x}$

$J_{\mathrm{K}}=n b F$

де $F=e E$ - сила, що діє на іон, $E$ - напруженість електричного поля, $b$ - рухомість іона, яку зв'язує $з$ коефіцієнтом дифузії співвідношення Ейнштейна:

$b k_{\mathrm{B}} T=D$.

Матимемо справу зі змінним струмом, тобто

$E=E_{0} \exp (-i \omega t)$

Як це видно з рис. 4, електропровідність зі зростанням частоти збільшується, але збільшується тільки до деякої частоти $\omega_{Q}$, що має порядок $10^{4} \mathrm{c}^{-1}$. При частотах, більших за $\omega_{Q}$, електропровідність практично не змінюється. Таку поведінку електропровідності можна пояснити так: згідно з формулами (11)-(13) дифузійний потік протидіє конвективному, зменшуючи останній. За високих частот зовнішньої сили, коли виконується нерівність

$\omega \tau_{Q} \gg 1$

дифузійні моди "не встигають слідкувати" за зовнішнім полем, так що при виконанні нерівності (16) дифузійний потік практично відсутній. Залишається тільки потік конвективний, i, відповідно, формула (10) набуває вигляду

$I=\frac{e^{2} n D}{k_{\mathrm{B}} T} E$.
3 цієї формули видно, що при виконанні умови (16) електропровідність $k$ визначається виразом

$k=\frac{e^{2} n D}{k_{\mathrm{B}} T}$.

Згідно з останнім виразом, електропровідність не залежить від частоти. Отже, ділянка сталої електропровідності відповідає нерівності (16). Це означає, що частота $\omega_{Q}, 3$ якої починається ця ділянка, визначається умовою

$\omega_{Q} \tau_{Q}=1$.

Згідно з формулою (7) концентрація записується у вигляді суми, кожен з доданків якої є колективною флуктуацією, синусоїдальною у просторі. Остання затухає експоненційно з часом релаксації (6). Таку затухаючу колективну флуктуацію називають, як уже згадувалось, дифузійною модою. Поява їі спричинена тим, що концентрація частинок (в даному випадку - іонів) є величина, що зберігається. Відповідно, надлишок цієї величини не може зникнути локально, а може лише повільно релаксувати, поширюючись по всій системі. Синусоїдальна дифузійна мода релаксує тільки шляхом перенесення частинок із області надлишкової в область недостатньої концентрації.

Після прикладання зовнішнього поля початковий розподіл іонів відповідає вже нерівноважному станові, тобто є флуктуацією відносно рівноважного розподілу, який визначається величиною поля. Точніше, в цьому випадку ми маємо справу з уже згадуваною сукупністю флуктуацій, кожна з яких характеризується своїм часом релаксації (6). Найменше значення цього часу було визначено як $\tau_{Q}$. Зрозуміло, що при виконанні умови (16) колективні флуктуації не встигатимуть релаксувати й електропровідність визначається формулою (18). У цю формулу входить концентрація. Ця величина характеризує певний стан локальної рівноваги й розраховується за допомогою локально-рівноважної функції розподілу [9]. Як уже згадувалось, наявність концентрації у формулі (18) означає, що в системі, яка знаходиться під дією зовнішнього змінного поля, в кожен момент часу встигає встановитись локальна рівновага. Іншими словами, якщо позначити через $\tau_{l}$ час її встановлення, то має бути виконана нерівність

$\omega \tau_{l} \ll 1$.

Впевнимось у правомірності формули (18). Згідно з нею незалежне від частоти значення питомої електропровідності $k$ має бути пропорційним концентрації $n$ 


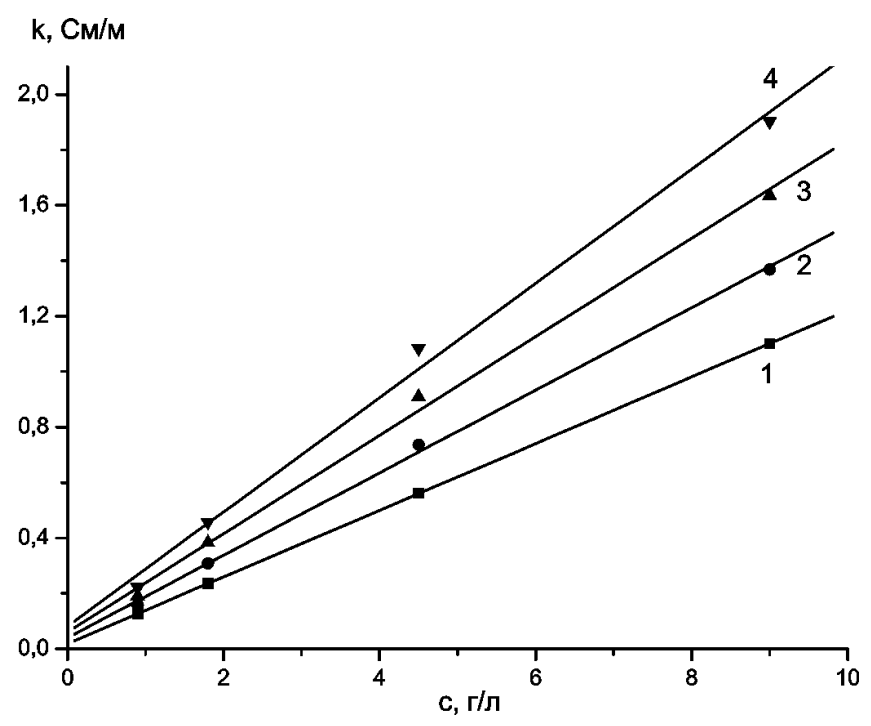

Рис. 6. Концентраційна залежність питомої електропровідності водного розчину натрію хлориду при температурах: $1-30{ }^{\circ} \mathrm{C}$, $2-40{ }^{\circ} \mathrm{C}, 3-50{ }^{\circ} \mathrm{C}, 4-60{ }^{\circ} \mathrm{C}$

при сталій температурі. На рис. 6 наведено експериментальні залежності питомої електропровідності $k$ від концентрації $n$ для різних температур.

Як видно з рис. 6, експериментальні залежності можна з задовільною точністю апроксимувати лінійними залежностями, що дозволяє розрахувати коефіцієнт дифузії $D$ з формули (18) та розмір нескінченно малого об'єму $l$ для досліджуваних розчинів, використовуючи формули (8), (9) (рис 7,8$)$.

Як це випливає із наведених графіків, величина $l$ за порядком становить $10^{3}$ нм.

Згідно з виразом (20) в системі повинні існувати швидкі релаксаційні процеси, які забезпечать встановлення локальної рівноваги. Такими можуть бути процеси релаксації дебаївської атмосфери, запропоновані в роботах П. Дебая [7, 8]. Час релаксації цих процесів становить $10^{-6}-10^{-7} \mathrm{c}^{-1}$. Водночас варто підкреслити, що розмір фізичного нескінченно малого об'єму суттєво перевищує дебаївський радіус $r_{\mathrm{D}}$. Дійсно, формула для дебаївського радіуса [7]:

$r_{\mathrm{D}}=\left(\frac{\varepsilon k_{\mathrm{B}} T}{8 \pi n e^{2}}\right)^{1 / 2}$

де $\varepsilon$ - діелектрична проникність розчинника, $e-$ заряд іона.

Підставивши в формулу (21) числові значення величин для нашого експерименту, отримаємо оцінку $r_{\mathrm{D}} \approx 0,8 \mathrm{Hм}$.

Для теорії Дебая справедливою є нерівність $l \ll r_{\mathrm{D}}$. Для нашого випадку $r_{\mathrm{D}} \ll l$. Це означає, що попере-

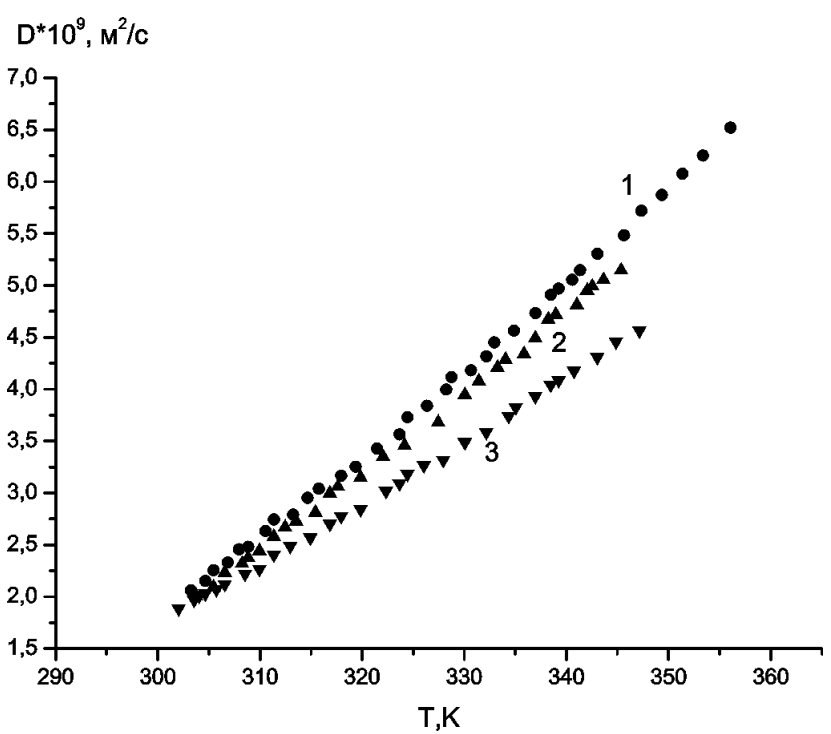

Рис. 7. Температурна залежність коефіцієнта дифузії водного розчину натрію хлориду з концентраціями $\mathrm{NaCl}: 1-1,8$ г·л, 2 $-4,5 \Gamma \cdot \pi, 3-9 \Gamma \cdot \pi$

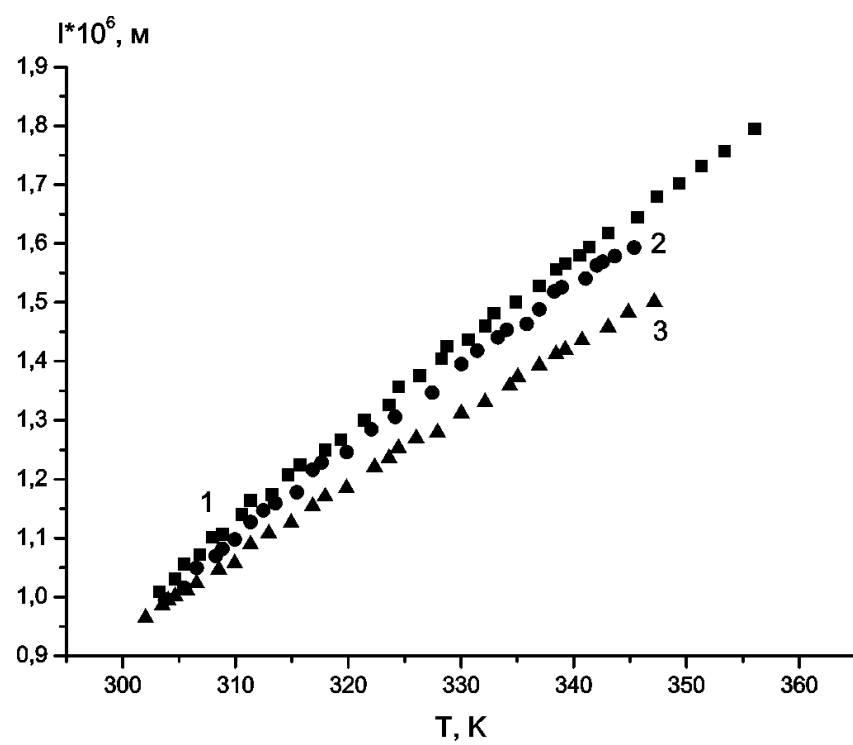

Рис. 8. Температурна залежність розміру фізичного нескінченно малого об'єму для водного розчину натрію хлориду з концентраціями $\mathrm{NaCl}: 1-1,8$ г·л, $2-4,5$ г·л, $3-9$ г·л

дня нерівність не виконується й теорія Дебая в нашому випадку не застосовна.

На доказ незастосовності теорії Дебая в нашому випадку можна навести ще такий аргумент. Згадана теорія зберігає свою силу за умови, що енергія взаємодії $U$ даного іона з іншими задовольняє умову $U \ll k_{\mathrm{B}} T$. Розрахуємо величину $U$ для концентрацій, досліджених у даній статті. Як відомо, за концентра- 
цій, які відповідають теорії Дебая, поблизу даного іона, який має, наприклад, позитивний заряд, концентрація негативних іонів перевищує концентрацію позитивних іонів. У нашому випадку, коли дебаївський радіус $r_{\mathrm{D}}$ за порядком величини стає рівним відстані між іонами $n^{-1 / 3}$, в найближчому оточенні - першій координаційній сфері - позитивного іона позитивні заряди практично відсутні: згаданий позитивний іон виявляється оточеним виключно негативними іонами. Рентгенографічні дослідження [9] показали, що число іонів у першій координаційній сфері приблизно таке ж, як і в кристалі. Ця обставина дозволяє використати для оцінки $U$ розрахунки, виконані для кристала $\mathrm{NaCl}$ [10], де для електростатичної енергії $U^{\prime}$, що припадає на одну комірку, тобто фактично для енергії взаємодії одного іона із оточенням, отримано значення

$U^{\prime}=1,75 e^{2} n^{1 / 3}$.

Враховуючи, що іони розчиненої речовини знаходяться в оточенні молекул води, попередню формулу для нашого випадку слід переписати у вигляді

$U=1,75 \frac{e^{2} n^{1 / 3}}{\varepsilon}$

Підставляючи в цю формулу значення $n$ із дослідженого інтервалу концентрацій, отримуємо $U \approx$ $5 \cdot 10^{-21}$ Дж, що має однаковий порядок з енергією теплового руху іона $k_{\mathrm{B}} T \approx 4 \cdot 10^{-21}$ Дж.

Якщо не враховувати відстані між молекулами розчинника, то в розчині електроліту можна виділити чотири характерні лінійні розміри: $n^{-1 / 3}-$ середня відстань між іонами, $l$ - розмір фізичного нескінченно малого об'єму, $r_{\mathrm{D}}$ - дебаївський радіус, $L$ - розмір системи. Теорія електропровідності Дебая застосовна для малих концентрацій іонів. Вона застосовна, коли виконуються нерівності

$n^{-1 / 3} \ll l \ll r_{\mathrm{D}} \ll L$.

Значення фізичного нескінченно малого об'єму, отримане $з$ проведеного в даній статті експерименту, виявилось за порядком величини $10^{-6}$ м. Крім того, для дослідженого інтервалу концентрацій середня відстань між іонами $n^{-1 / 3}$ та дебаївський радіус $r_{\mathrm{D}}$ мають однаковий порядок величини, оскільки для дослідженого інтервалу концентрацій $n^{-1 / 3}=(0,2-$ 0,5) нм.

Іншими словами, для інтервалу концентрацій, дослідженого в даній статті, виконуються нерівності

$n^{-1 / 3}, \quad r_{\mathrm{D}} \ll l \ll L$.
Відповідно до ієрархії просторових розмірів (25) повинна існувати часова ієрархія

$\tau_{\mathrm{D}} \ll \tau_{l} \ll \tau_{L}$,

де $\tau_{\mathrm{D}}$ - час формування дебаївської атмосфери, $\tau_{l}-$ час встановлення локальної рівноваги, $\tau_{L}$ - час встановлення рівноваги в усій системі.

Фактично, в даному випадку, коли $n^{-1 / 3} \approx r_{\mathrm{D}}$, утворення дебаївської атмосфери відповідає утворенню ближнього порядку в системі іонів. Крім того, встановлення рівноваги в усій системі являє собою сукупність релаксаційних процесів із часами релаксації, що визначається за формулою (6).

Таким чином, вводячи час релаксації $\tau_{L}$, ми тим самим умовно розуміємо під цією величиною існування спектра часів релаксації, найменше з яких дорівнює $\tau_{Q}$, тобто вираз (26) слід переписати у вигляді

$\tau_{\mathrm{D}} \ll \tau_{l} \ll \tau_{Q}$.

Існування ієрархї (27) і визначає частотну область, в якій спостерігається незалежність електропровідності від частоти, а саме: це - частоти, які відповідають нерівності

$\tau_{l} \ll \omega^{-1} \ll \tau_{Q}$.

Таким чином, поява частотно-незалежної електропровідності в розчинах електролітів викликана існуванням релаксаційного процесу, який характеризується часом релаксації $\tau_{l}$, який приводить до виникнення стану локальної рівноваги. Цей тип електропровідності реалізується, коли період зовнішнього поля стає набагато більшим за час встановлення локальної рівноваги і в той же час залишається набагато меншим за час $\tau_{Q}$ дифузійних процесів.

\section{5. Висновки}

У розчинах електролітів існує ієрархія часів релаксації. Вона являє собою послідовність зростаючих значень часів, які відповідають таким процесам: формуванню дебаївської атмосфери, встановленню локальної рівноваги та релаксації сукупності дифузійних мод.

В тому випадку, коли період зовнішнього електричного поля більший за час встановлення локальної рівноваги, але менший за часи релаксації дифузійних мод, електропровідність розчину електроліту виявляється незалежною від частоти зовнішнього поля. В цьому випадку дифузійний потік іонів відсутній, peалізується ж виключно конвективний потік. 
Ця обставина дозволяє за значеннями електропровідності, експериментально визначеними в згаданому інтервалі частот, розрахувати коефіцієнт дифузї іонів. За значенням нижньої границі частотного інтервалу, де електропровідність не залежить від частоти, розраховується значення фізичного нескінченно малого об'єму, в якому встановлюється локальна рівновага.

1. Б.А. Лопатин, Теоретические основы электрохимических методов анализа (Высш. школа, Москва, 1975).

2. Л.Д. Ландау, Е.М. Лифшиц, Гидродинамика (Наука, Москва, 1988).

3. Ю.Л. Климонтович, Статистическая физика (Наука, Москва, 1982).

4. К.П. Гуров, Феноменологическая термодинамика необратимых процессов (Наука, Москва, 1978).

5. E.M. Lifshitz and L.P. Pitaevskii, Physical Kinetics (Pergamon Press, New York, 1981).

6. P. Debye and E. Hückel, Phys. Z. 24, 185 (1923).

7. P. Debye and H. Falkenhagen, Phys. Z. 29, 401 (1928).

8. Д.Н. Зубарев, Неравновесная статистическая термодинамика (Наука, Москва, 1971).

9. А.Ф. Скрышевский, Дифракиия рентгеновских лучей, электронов и нейтронов в газах и строение молекул (Изд-во Киевского ун-та, Киев, 1961).

10. G. Leibfried, Gittertheorie der Mechanischen und Thermischen Eigenschaften der Kristalle (Springer, Berlin, 1955).

Одержано 28.01.11

\section{МЕХАНИЗМ ЧАСТОТНО-НЕЗАВИСИМОЙ \\ ЭЛЕКТРОПРОВОДНОСТИ ВОДНЫХ \\ РАСТВОРОВ ЭЛЕКТРОЛИТОВ}

Л.А. Булавин, А.Н. Алексеев, Ю.Ф. Забашта, С.Ю. Ткачев

Р е з ю м е

Показано, что поведение зависимости сопротивления ячейки с водным раствором $\mathrm{NaCl}$ от частоты переменного тока в вы- бранном приближении не может быть объяснено только поляризационными явлениями в граничных областях электродэлектролит. Предложен физический механизм, который объясняет монотонное возрастание удельной электропроводности раствора при возрастании частоты, когда частота не превышает $10^{4}$ Гц, и постоянство удельной электропроводности раствора при частотах в интервале $\left(10^{4}-10^{5}\right)$ Гц. Рассчитаны температурные зависимости коэффициента диффузии ионов $\mathrm{Na}^{+}$и $\mathrm{Cl}^{-}$в водных растворах $\mathrm{NaCl}$ и размера физического бесконечно малого объёма (области установления локального равновесия) для такого электролита. Проведен анализ пространственной и временной иерархии в водном растворе $\mathrm{NaCl}$ и показана связь соотношения периода переменного тока и определённых характерных времен с частотной зависимостью удельной электропроводности этого электролита.

\section{MECHANISM OF FREQUENCY-INDEPENDENT CONDUCTIVITY IN AQUEOUS SOLUTIONS OF ELECTROLYTES}

\section{L.A. Bulavin, A.N. Alekseev, Yu.F. Zabashta, S.Yu. Tkachev}

Taras Shevchenko National University of Kyiv, Faculty of Physics (4, Academician Glushkov Prosp., Kyiv 03680, Ukraine; e-mail: tkachevserg@gmail.com)

$\mathrm{S} \mathrm{u} \mathrm{m} \mathrm{m} \mathrm{a} \mathrm{r} \mathrm{y}$

It is shown that the dependence of the resistance of a cell filled with a $\mathrm{NaCl}$ aqueous solution on the ac frequency cannot be explained as a result of only polarization phenomena in the boundary region at the electrode-electrolyte interface. A physical mechanism is proposed, which explains the monotonous increase of the solution specific conductivity at frequencies below $10^{4} \mathrm{~Hz}$, and its constant value in the frequency interval of $10^{4}-10^{5} \mathrm{~Hz}$. The temperature dependences for the diffusion coefficients of $\mathrm{Na}^{+}$and $\mathrm{Cl}^{-}$ ions in $\mathrm{NaCl}$ aqueous solutions and for the dimension of an physically infinitesimal volume (a region, where the local equilibrium is established) in this electrolyte are calculated. The space-time hierarchies in the $\mathrm{NaCl}$ aqueous solution are analyzed, and a relationship between a connection of the ac period with certain time characteristics, on the one hand, and the frequency dependence of the specific conductivity in this electrolyte, on the other hand, is demonstrated. 